\title{
Access and the non-custodial parent in the Republic of Ireland
}

\author{
DR ANNE EgAN*
}

School of Law, National University of Ireland Galway, Ireland

\begin{abstract}
$\underline{\text { Abstract }}$
Maintaining a relationship between parents and children following the breakdown of a marriage or relationship can be franght with difficulties, particularly where acrimony exists between parents. This article explores the right of a non-custodial parent to have access to their child under Irish law and discusses the results of an interview-based study undertaken by the author using qualitative research methods. The interviewees in the study included practitioners as well as separated, divorced and unmarried fathers and mothers who outlined their views on access and the study found that the majority of non-custodial parents had some level of access to their child. The article further outlines the author's experience of successfully applying to attend family court as a bona fide researcher and discusses some of the results of observations in those courts which reinforced the results of the interview-based study. Article 9(3) of the United Nations Convention on the Rights of the Child (CRC) states that in the event of separation of parents, it is the right of the child to maintain personal relations and contact with both parents. Article 7(1) of the Convention further supports the right of a child to be cared for by his or her parents. These articles have proved useful for fathers' rights campaigners who advocate that they should have more contact with their children post-separation. The Convention, however, while ratified by Ireland, has not yet been incorporated into Irish law. The article concludes by examining whether the incorporation of the Convention would advance the rights of Irish children to maintain a relationship with their parents, unless such a relationship would be contrary to the children's best interests. In light of this, this article examines the proposed wording of the Constitutional Referendum on Children which was published in early 2010 and assesses what impact the passing of such a referendum would have on children's rights in Ireland.
\end{abstract}

\section{Introduction}

耳ollowing the breakdown of a marriage or relationship, the right of a child to have access With the non-custodial parent is governed in the Republic of Ireland (hereinafter referred to as "Ireland") by the Guardianship of Infants Act $1964 .{ }^{1}$ This statute permits the court to make an order for custody to decide with whom the child should live on a day-today basis. It also gives leave to the court to make orders for access so that the non-custodial parent (usually the father) is given permission to visit the child on specific dates and at

* Dr Anne Egan is a university fellow in teaching and research and lecturer in family law at the National University of Ireland Galway.

1 As amended by the Status of Children Act 1987 and the Children Act 1997. 
specified times. ${ }^{2}$ The right of a child to maintain contact with his or her parents is an integral part of the CRC. This Convention has placed children's rights at the heart of legislative provisions worldwide. Further, as it was the "first binding universal treaty dedicated solely to the protection of children's rights", 3 it firmly placed the child as an autonomous person at the centre of human rights issues. It applies to all children under the age of 18 years. ${ }^{4}$ While Ireland has ratified the Convention, it is not yet part of domestic law. This article will focus on the provision of access to the non-custodial parent and will address how the incorporation of the Convention could strengthen a child's right to have continued involvement with his or her parents after separation or relationship breakdown. It will further examine the text of the proposed wording of the Constitutional Referendum on Children, which if adopted, could be instrumental in paving the way for the Convention to become part of Irish domestic law.

\section{Ireland and the Convention}

When the CRC was opened for signature in 1990, Ireland was one of the 61 states to sign up. The CRC was subsequently ratified by Ireland in 1992 and entered into force in October of the same year. Ireland takes a dualist approach to international law. In the Constitution of 1937, Article 15 gives sole and exclusive power to the Oireachtas to make laws and Article 29 provides that for an international treaty to be a source of law domestically, it must have been specifically incorporated into domestic law. 5

This means that international and domestic law are viewed as two separate legal systems and international law only impacts on domestic law to the extent to which it is incorporated into Irish legislation. As a result, not all international agreements to which Ireland becomes a party are automatically incorporated into domestic law. ${ }^{6}$ Therefore, as the CRC has not yet been incorporated it is not legally binding. As a result it cannot be relied on in Irish Courts but may be used as a "source of guidance, rather than a source of hard law". 7 Fottrell argues that domestic courts have relied on the Convention for guidance and when this occurs, it raises the existing standards in that state. ${ }^{8}$ Having ratified the Convention, there is a duty on

2 S. 9 of the Children Act 1997 inserted a new s. 11B into the Guardianship of Infants Act 1964 which provides that any person who is related to the child or has acted in loco parentis to a child can apply to the court for access to that child. S. $11 \mathrm{~B}(2)$ of the Principal Act provides that relatives must first apply and be granted leave by the court to make an application for access.

3 D Fottrell, Revisiting Children's Rights: 10 years of the UN Convention on the Rights of the Child (The Hague: Kluwer Law International 2000), p. 1.

4 Article 1 of the Convention states that a child is someone under 18 years of age unless the age of majority is attained at an earlier age under domestic law.

5 Article 15.2.1 of the Constitution states: "The sole and exclusive power of making laws for the State is hereby vested in the Oireachtas: no other legislative authority has power to make laws for the State." Article 15.2.2. states: "Provision may however be made by law for the creation or recognition of subordinate legislatures and for the powers and functions of these legislatures." Article 29.6 states: "No international agreement shall be part of the domestic law of the State save as may be determined by the Oireachtas." Note: Oireachtas is the national parliament of Ireland.

6 For example, in Re O'Láighleis [1960] IR 93, the applicant argued that the Offences Against the State (Amendment) Act 1940, under which he had been interned, was inconsistent with the European Convention on Human Rights. Maguire CJ in the Supreme Court held that the "Oireachtas has not determined that the Convention of Human Rights and Fundamental Freedoms is to be part of domestic law of the State, and accordingly this Court cannot give effect to the Convention if it be contrary to domestic law or purports to grant rights or impose obligations additional to those of domestic law": p. 125.

7 Law Society Law Reform Committee, Rights-based Child Law: The case for reform (Dublin: Law Reform Committee of the Law Society of Ireland 2006) p. 7.

8 Fottrell, Revisiting Children's Rights, n. 3 above, p.13. 
the state to ensure that children's rights are enshrined in all domestic law and policy and domestic legislation must comply with the minimum standards outlined in the Convention.

As with all state parties to the CRC, Ireland is obliged to submit periodic reports every five years to the Committee on the Rights of the Child. In its first report in 1996, the Committee observed that there was a lack of guarantees for the child to maintain contact with both parents after divorce, and that the views of the child were not generally taken into account. ${ }^{9}$ The Committee recommended the publication of a National Children's Strategy. This strategy entitled Our children - their lives was published in 2000 after extensive consultation with parents, children and interest groups. The 10-year plan of this strategy is to improve the quality of children's lives, including the right of children to have a voice in matters affecting them. ${ }^{10}$ The second report in $2005^{11}$ and the concluding observations by the Committee in $2006^{12}$ stated that while some progress had been made, there were concerns that "the adoption of a child rights-based approach in policies and practices" had not been sufficiently progressed. ${ }^{13}$ In particular, the Committee recommended that the best-interests principle be fully integrated in all legislation relating to children and that children should be provided with an opportunity to be heard in any proceedings affecting them with due weight to be given to their views, especially in circumstances where children have been separated from their parents. ${ }^{14}$

\section{Maintaining contact under the CRC}

A number of articles have particular importance in relation to a child's right to maintain contact with his or her parents. In particular, Article 7 of the CRC states:

The child shall be registered immediately after birth and shall have the right from birth to a name, the right to acquire a nationality and, as far as possible, the right to know and be cared for by his or her parents.

Further, Article 9(1) specifies:

State Parties shall ensure that a child shall not be separated from his or her parents against their will, except ... that such separation is necessary for the best interests of the child.

More particularly, Article 9(3) gives the strongest indication of the right of the child to maintain contact as it states:

State Parties shall respect the right of the child who is separated from one or both parents to maintain personal relations and direct contact with both parents on a regular basis, except if it is contrary to the child's best interests. ${ }^{15}$

The CRC was the first international treaty to confirm the relevance of participation rights of children. Article 12 requires state parties to ensure that due weight is given to the views of the child, and that children who are capable of expressing views be heard in all matters concerning them. It provides:

9 Ireland's First Report to the Committee on the Rights of the Child (Dublin: Stationery Office 1996), paras 15-20.

10 National Children's Office, The National Children's Strategy: Our children - their lives (Dublin: Stationery Office 2000), pp. 29-36.

11 Ireland's Second Report to the Committee on the Rights of the Child (Dublin: Stationery Office 2005).

12 Committee on the Rights of the Child, Concluding Observations on Ireland, CRC/C/IRL/CO/2 (2006).

13 Ibid. para. 6 .

14 Ibid. paras 5-6.

15 The wording of Article 9(3) is similar to Article 24(3) of the EU Charter of Fundamental Rights which states: "Every child shall have the right to maintain on a regular basis a personal relationship and direct contact with both his or her parents, unless that is contrary to his or her interests." 
State Parties shall assure to the child who is capable of forming his or her own views the right to express those views freely in all matters affecting the child, the views of the child being given due weight in accordance with the age and maturity of the child.

As previously mentioned, the CRC has not been incorporated into Irish law but the principles outlined in the Convention have, however, been influential in the Irish courts as a source of guidance in family law cases since its ratification. For example, in $N v N^{16}$ a father claimed that his six-year-old child was being unlawfully retained in Ireland and brought proceedings for the prompt return of his child under Article 12 of the Hague Convention. ${ }^{17}$ The key question for the courts was whether the child had a right to be heard under Article 11(2) of Council Regulation 2201/2003. ${ }^{18}$ Finlay-Geoghegan J commented in applying Article 11(2) that "it appears to me that it is permissible to have regard to Article 12 of the UN Convention on the Rights of the Child". ${ }^{19}$ Hence, the judge concluded that the child had a right to be heard in proceedings affecting him. ${ }^{20}$

Further, the principles in the CRC have been influential in the European Court of Human Rights (ECtHR). For example, in Keegan $\mathrm{v}$ Ireland, ${ }^{21}$ the ECtHR referred to Article 7 of the CRC and acknowledged that a child has, as far as possible, a right to be cared for by both parents. ${ }^{22}$ In this case an unmarried father whose relationship with the child's mother broke up prior to the birth of his child applied unsuccessfully to the Irish courts for guardianship and custody of the child. ${ }^{23}$ The child was subsequently placed for adoption by the mother, against the wishes of the father. At that time, the consent of the child's father was not required unless he had been appointed a guardian of the child, or had care or control over the child at the relevant time, nor had he a right (at that time) to be consulted in relation to any such adoption. ${ }^{24}$

Mr Keegan was appointed a guardian and awarded custody of the child in the Circuit Court but this was appealed to the High Court. Barron J in that court applied a two-part test to determine:

(1) whether the natural father is a fit person to be appointed as guardian, and, if so:

(2) whether there are circumstances involving the welfare of the child which require that, notwithstanding he is a fit person, he should not be so appointed. 25

Barron J sent the case to the Supreme Court for an opinion on the test he had formulated. Finlay CJ held in that court that the test applied in the High Court was incorrect

16 [2008] IEHC 382.

17 Hague Convention on the Civil Aspects of International Child Abduction.

18 Also known as Brusells II bis or revised Brusells II.

19 [2008] IEHC 382, para. 25.

20 Finlay-Geoghegan J did observe that "[i]n general, the weight to be attached to views expressed by a six year old as to the country in which he would like to live will be less than that to be attached to the views of say a fifteen year old": ibid. para. 31.

21 Case 16969/90, Keegan v Ireland (judgment of 26 May 1994).

22 Ibid. para. 362.

$23 J K_{\mathrm{v}} V W[1990] 2$ IR 437. The birth of this child was planned and the couple were engaged to be married at one point.

24 S. 14 of the Adoption Act 1952 which stated: "An adoption order shall not be made without the consent of every person being the child's mother or guardian or having charge of or control over the child, unless the Board dispenses with any such consent in accordance with this section." 
as it gave an unmarried father an automatic right to guardianship. If this was the case, the father's consent would be required for the adoption order to be legalised. ${ }^{26}$ While the Supreme Court did acknowledge that Mr Keegan had the welfare of the child at heart, it concluded that a natural father did not have an automatic constitutional right to be a guardian, but rather he merely had a right to apply for same. This did not equate his position with that of a married father. ${ }^{27}$ The case was returned to the High Court where Barron J concluded that the child remain with her adoptive parents because, if she was removed, she would be in danger of suffering psychological trauma or insecurity by breaking the bonds of attachment with her adoptive parents. ${ }^{28}$

Subsequently, the case was appealed to the ECtHR where the applicant complained that there had been a violation of his right to respect for family life under Article 8 of the Convention, because the child had been placed for adoption without his knowledge or consent. The ECtHR held that the natural father was placed at a considerable disadvantage under Irish law as he was not informed of the adoption of his child. ${ }^{29}$ In referring to the CRC, the court noted:

It is, moreover, appropriate to recall that the mutual enjoyment by parent and child of each other's company constitutes a fundamental element of family life even when the relationship between the parents has broken down. ${ }^{30}$

This case was influential in that the legislature subsequently introduced the Adoption Act 1998 which gives unmarried fathers a right to be consulted prior to the adoption of their child. 31

\section{Access under contemporary Irish legislation}

In Ireland, guardianship, custody and access are governed by the Guardianship of Infants Act $1964 .{ }^{32}$ Where couples have been married, the father is an automatic guardian sharing guardianship jointly with the child's mother, he will most likely be granted joint custody and unless exceptional circumstances prevail, will have access to his children. Unmarried fathers are not automatic guardians but have a right to apply for guardianship under s. 12 of the Status of Children Act $1987^{33}$ or by agreement with the mother under s. 4 of the Children Act 1997. An unmarried father may apply for custody or access in respect of his child whether or not he also enjoys guardianship rights. Unmarried fathers, however, have no automatic right to guardianship and hence do not have a right to make major decisions in relation to their children, especially in relation to education, religion and consent to medical

26 [1990] 2 IR 437, para. 444.

27 Ibid. para. 446. Finlay CJ stated that the rights of any father would depend on the intensity of the particular relationship between the father and child and that where a child was conceived as a result of casual intercourse, then a father's "rights might well be so minimal as practically to be non-existent": at para. 447.

28 Ibid. para. 461.

29 Keegan $\mathrm{v}$ Ireland, n. 21 above, para. 46.

30 Ibid. para. 50

31 S. 6 of the Adoption Act 1998, inserted a new s. 19A into the principal adoption legislation, being the Adoption Act 1952. In the Keegan case, as the child had been with her prospective adoptive parents for over two years and had bonded, the adoption took place.

32 In 2009, the Law Reform Commission published its Consultation Paper on the Legal Aspects of Family Relationships (LRC CP55-2009) and recommended the replacing of the terms "guardianship", "custody" and "access" with the terms "parental responsibility", "day-to-day care" and "contact", respectively.

33 S. 12 of the Status of Children Act 1987 inserted a new s. 6A into the Principal Act, being the Guardianship of Infants Act 1964. 
treatment or the signing of passport forms for children under the age of 18 years. ${ }^{34}$ In theory, when couples separate, the child may reside with either parent, unless the court directs otherwise. In practice, however, the mother is usually the parent with whom the child lives on a day-to-day basis and the father will invariably be granted access rights either by agreement or by the court. Coulter's study of Circuit Family Court cases in Ireland found that in almost 60 per cent of cases, children lived with their mother following the breakdown of a marriage. ${ }^{35}$

Children can also have restricted access to their parents if they are taken into care. Under the Child Care Act 1991 children may be taken into care on a voluntary basis. ${ }^{36}$ In the alternative, if exceptional circumstances exist, they can be taken into care without their parents' consent where the child has been, or is suspected of being, abused, neglected or illtreated in any manner. ${ }^{37}$ However, s. 37 of the 1991 Act requires the state and its agent, being the Health Service Executive, to facilitate where possible, access for children who have been taken into care, whether compulsory or voluntary. ${ }^{38}$ Such access is subject at all times to the best interests of the child in question. This right of access to children in care has also been recognised by the ECtHR when, in Eriksson $\mathrm{v}$ Sweden, ${ }^{39}$ the court held that a child's relationship with his or her family is not terminated by reason of the fact that the child has been taken into care and, as a result, Sweden was found to be in breach of Article 8 of the European Convention on Human Rights. ${ }^{40}$ Further, in Olsson v Sweden ${ }^{41}$ it was held that Article 8 was not violated by taking children into care but "it is an inference of a very serious order to split up a family" 42 and therefore the implementation of the care order gave rise of a breach of Article 8 as the maintenance of access between the family was not feasible.

For most children, the difficulty in maintaining contact with their parents is as a result of separation and divorce. Fathers' rights groups often complain that it is difficult for fathers to maintain contact with their children as there is a "generalisation that fathers do not want to look after their children or have custody of their children". ${ }^{43}$ In the 1970 s, Wrangham $\mathrm{J}$ in $M \mathrm{v} M^{44}$ described access as "a basic right in the child rather than a basic

34 S. 14 of the Passports Act 2008 permits the issuing of passports for children without the consent of a guardian. S. 14(3) of the Act states: "the Minister [Minister for Foreign Affairs] may issue a passport to a child without the consent to such issue of a guardian of the child if a court in the State makes an order directing that a passport may be issued to the child without the consent to such issue of that guardian of the child." S. 14(5) permits the issuing of the passport if it is not practicable or appropriate to obtain permission, including if the first named guardian and child are ordinarily resident outside the state, unless the parents have objected in writing to the issuing of such a passport.

35 C Coulter, Family Law in Practice: A study of cases in the Circuit Court (Dublin: Clarus Press 2009), p. 121.

36 S. 4 of the Child Care Act 1991.

37 The court has the power to make an emergency care order (s. 13), interim care order (s. 17) or a care order (s. 18).

38 S. 37(1) states: "Where a child is in the care of a health board . . . the board shall, subject to the provision of this Act, facilitate reasonable access to the child by his parents, any persons acting in loco parentis, or any other person who, in the opinion of the board, has a bona fide interest in the child and such access may include allowing the child to reside temporarily with any such person." The Health Service Executive is the successor to the health boards.

39 Case 11373/85, Eriksson $\mathrm{v}$ Sweden (judgment of 22 June 1989).

40 Ibid. para. 58.

41 Case 10465/83, Olsson v Sweden (judgment of 24 March 1988).

42 Ibid. para. 72. The children had been placed separately in care from each other and their parents.

43 Available at www.fathers.ie. This group, formerly called Fathers for Justice and Equality have recently been renamed as Families, Fathers and Friends.

44 [1973] 2 All ER 81. 
right in the parents". ${ }^{45}$ Further, in $M D$ v GD, ${ }^{46}$ Carroll J held that s. 11(1) of the $1964 \mathrm{Act}^{47}$ enables the court to make access orders allowing children access to persons other than their natural parents, on the basis that "it is the right of the child with which the court is concerned, not the right of the adult". ${ }^{48}$

In light of this, an essential element of access is that children, where appropriate, should have the opportunity to be heard in order to ascertain their wishes. Section 25 of the Guardianship of Infants Act $1964{ }^{49}$ provides for a court "as it thinks appropriate and practicable having regard to the age and understanding of the child, [to] take into account the child's wishes in the matter". In $W \mathrm{v} W,{ }^{50}$ two boys aged 14 and 12 were interviewed by a judge and expressed a view that they would run away if they had to live with their mother. Kenny J stated that "when children of this age express such a strong preference for living with one of their parents, the Court should give effect to it". 51 The obligation to hear a child will depend on that child's understanding and maturity and in Hokkanen v Finland 52 the ECtHR held that "the obligation of the national authorities to take measures to facilitate reunion is not absolute". 53

In order for children's voices to be heard in proceedings affecting them, mechanisms must be implemented to ensure that appropriate professionals can assist children in having their voices heard. In custody and access cases, some judges speak to children in their chambers. Coulter nonetheless points out that, while some judges meet children in chambers and speak to them, "others do not do so, suspecting that the children may be manipulated by one parent and not wishing to involve them [the children] in their parents' dispute". ${ }^{54}$ Further, s. 28 of the Guardianship of Infants Act 196455 makes provision for the views of the child to be ascertained in guardianship, custody and access cases, by means of the appointment of a guardian ad litem (commonly known as GAL). ${ }^{56}$ A GAL is a separate legal representative for a child, who acts on behalf of the child in proceedings affecting him or her and protects the child's interests. In appointing a GAL, the court should take a number of matters into consideration, namely the welfare of the child ${ }^{57}$ and the age and understanding of the child. ${ }^{58}$ Section 28 specifies that "special circumstances" must exist before a GAL may be appointed but there is no definition as to what these

45 [1973] 2 All ER 81 para. 85.

46 High Court, unreported, July 1992.

47 S. 11(1) of the 1964 Act: "Any person being a guardian of an infant may apply to the Court for its direction on any question affecting the welfare of the infant and the Court may make such order as it thinks proper."

48 See n. 46 above, p. 12.

49 As inserted by s.11 of the Children Act 1997.

50 Unreported, Supreme Court, June 1975.

51 Ibid. para. 3. The mother in this case was granted access to the children although the children expressed a wish that they did not want weekend access as it would interfere with their weekend activities.

52 Case 19823/92, Hokkanen v Finland (judgment of 23 September 1994).

53 Ibid. para. 58. In this case, a 12-year-old child's decision not to have access to her father was taken into account.

54 Courts Service, Family Law Report Pilot Project (Dublin: Courts Service 2007), p. 44. In 2005, Carol Coulter was appointed by the Courts Service to attend family law court proceedings for one year on a pilot basis: see www.courts.ie/Courts.ie/Library3.nsf/0/4A925BEEEE71148580257245005EEA1C?OpenDocument.

55 Inserted by s. 11 of the Children Act 1997.

56 S. 28 of the Guardianship of Infants Act 1964 states: "If in proceedings under section 6A, 11 or 11B the child to whom the proceedings relate is not a party, the court may, if satisfied that having regard to the special circumstances of the case it is necessary in the best interest of the child to do so, appoint a guardian ad litem for the child."

57 S. 28(2)(c) of the Guardianship of Infants Act 1964.

58 Ibid. s. 28(2)(a). 
"special circumstances" are. It appears, therefore, that appointment would only be made in limited circumstances and when it is in the best interests of the child to do so. Further, as Daly argues, in "private law proceedings, it is the parties themselves (or any other party identified by the court) who must bear the cost of the appointment of a guardian ad litem". ${ }^{59}$ It appears therefore that such appointments are only made in custody and access cases where severe animosity exists. Unfortunately, even though the provision allowing for the appointment of a GAL in private law proceedings was passed in 1997, this section has not yet been brought into operation. ${ }^{60}$

Fathers' rights groups have been very vocal in their opposition to what they perceive as a bias against them in the family law courts system and argue that the law and courts are gender-biased. ${ }^{61}$ These groups have also accused mothers of false and malicious claims against fathers to prevent access taking place, and describe mothers as vindictive and selfish women who routinely refuse to obey contact orders. ${ }^{62}$ Kilkelly observes that "Irish law has made no provision, nor does it offer any guidance to the courts for dealing effectively and appropriately with allegations of sexual abuse raised in custody/access cases." 63 In an interview-based study conducted by the author, one father who was a custodian spoke passionately about allegations of abuse made against him by the child's mother during the custody hearing. He was questioned about but never prosecuted for these offences. ${ }^{64}$

The term used to describe a situation where the custodial parent refuses access to the other parent is called parental alienation syndrome. Shannon states that the "alienation can be due to overt or covert actions by the custodial parent designed to turn the child against the absent parent". ${ }^{65}$ In the interview-based study, over 60 per cent of fathers interviewed stated that frustration of their access had occurred, while over a quarter of the mothers (36 per cent) admitted that they had refused the father access, but only when they believed the child was in danger. ${ }^{66}$

Rhoades argues that fathers want recognition that they play an equally important role as mothers in their children's lives "regardless of their past inexperience as carers or the father's inability to spend significant periods of time with the children". ${ }^{67}$ In fact, Bainham makes the point that a feature of Articles 7 and 9 of the $\mathrm{CRC}$ is that "no distinction is

59 A Daly, "Limited guidance: the provision of guardian ad litem services in Ireland" (2010) 13(1) Irish Journal of Family Law 8-11.

60 Although the Child Care (Amendment) Act 2010 provides clarity in relation to the appointment of a GAL, this Act only relates to public law proceedings. The Act outlines the criteria for the appointment of a GAL, the qualifications required and specifies that the Health Service Executive can apply for costs in relation to any party (Part II, s. 12). For further discussion on this Act, see N Carr, "Child Care (Amendment) Bill 2009 - an attempt to arbitrate on a system's logic" (2010) 13(3) Irish Journal of Family Law 63-9.

61 B Geldof, "The real love that dare not speak its name", in A Bainham, B Lindley, M Richards and L Trinder (eds), Children and their Families (Oxford: OUP 2003), pp. 171-200, p. 181.

62 R Collier and S Sheldon, (eds), Fathers Rights Activism and Law Reform in Comparative Perspective (Oxford: Hart Publishing 2006), pp. 63-5.

63 U Kilkelly, Children's Rights in Ireland: Law policy and practice (Dublin: Tottel Publishing 2008), p. 154. Although, in practice, if allegations of this nature have been made, a judge would probably order supervised access to the child.

64 See general discussion on the interview-based study later in this article.

65 G Shannon, Child Law 2nd edn (Dublin: Round Hall 2010), p. 741.

66 The custodial fathers in the study also acknowledged that they too refused to let the children's mother have access to the child where they believed the mother was unfit to see the child as a result of alcohol or drug addictions.

67 H Rhoades, in Collier and Sheldon (eds), Fathers Rights Activism, n. 62 above, pp. 125-46, p. 143. 
drawn between mothers and fathers". ${ }^{68}$ Therefore, the right to access with one's child is not based on the gender of the parent but rather on who is the non-custodial parent. In many cases, however, fathers' employment schedules do not in reality leave room for day-to-day care or indeed shared parenting. Shared parenting might not be in a child's best interests if there is a volatile relationship between the parents, as a child could be psychologically damaged by a negative relationship between the parents. Fathers' rights groups have suggested that Article 9(3) supports their claim that children have a right to maintain contact with fathers. For example, one fathers' rights group in Ireland, Parental Equality, in a submission to the All-Party Oireachtas Committee on the Constitution in 1997, argued that when a child is born "the State, through the Constitution should acknowledge the child's right to the care and protection of both parents from the moment of birth". ${ }^{9}$

When children have access to their non-custodial parent, the norm is that children visit the parents at specified times. Interestingly, while Article 9 of the CRC refers to direct and regular contact it does not specify that such contact has to be physical contact. It is acknowledged, however, that the best possible solution for any child is to have physical contact. Doek, writing on Article 9, interestingly argues that, in situations where it is impossible for direct and regular contact to be maintained, this does not mean that personal relations cannot be maintained through email, telephone and correspondence. ${ }^{70}$ In fact, the Irish courts in the past have deemed fit to order that parents have access with their children through such means. In FN and Another v CO and Others, ${ }^{71}$ the High Court refused a custody application on behalf of a father of two teenage girls who was himself living in England. ${ }^{72}$ Finlay-Geoghegan J stated that "it is in the interests of the welfare of the girls that they be encouraged to have increasing contact with their father". ${ }^{73}$ The judge ordered increased access between the father and his daughters by means of weekly telephone calls and unlimited email access as the father thought fit. ${ }^{74}$ Further, during the author's observations in the family courts, ${ }^{75}$ it was noted that judges ordered that children have telephone access with the non-custodial parent, particularly in circumstances where this parent did not live in close proximity to the custodial parent's home or where it was not feasible for that parent to have access to the child mid-week. ${ }^{76}$ Even though Doek was writing as recently as 2006, advances in technology such as Skype and social-networking sites mean that children can maintain contact not only by the written word, but also interactively. Technology is particularly important when parents do not live close to one another, as it can bring the more distant parent back into the lives of their children, although Welsh comments that such technologies should be "used only as a supplement to actual parent time" and should

68 Bainham et al., Children, n. 61 above, p. 62.

69 Available at www.parentalequality.ie/pe/images/preJune2008/pdf/submissions. At present, Article 41 of the Constitution of Ireland only recognises a marital union, while caselaw has held that Article 40.3 gives constitutional rights to unmarried mothers who are seen as having the right to the care and custody of their children. See discussion on the Constitution further in this article.

$70 \mathrm{~J}$ E Doek, A Commentary on the United Nations Convention on the Rights of the Child (Leiden: Martinus Nijhoff 2006), p. 30.

71 [2004] 4 IR 313.

72 The girls were living in Ireland with their maternal grandparents following the death of their mother and had settled.

73 [2004] 4 IR 313, para. 328.

74 Ibid. para. 329. The judge observed that physical access visits could be organised during school holidays but felt that it was important that visiting periods be gradually built up.

75 See discussion on observations in the family courts in Ireland later in this article.

76 In one case, a judge also ordered children to have regular telephone access with their grandparents who lived overseas. For a discussion on the rights of grandparents in Ireland, see A Egan and R McNamara, "Grandparents and the law in Ireland" (2010) 13(2) Irish Journal of Family Law 27-38. 
not replace actual visiting time. ${ }^{77}$ Doek had suggested that legislative measures be introduced to include a provision which would provide the right of the child to maintain personal relations by other means in circumstances where direct and regular contact was not logistically possible. ${ }^{78}$ In an Irish context, while there is no express legislative provision providing for access in this manner, the FN case is an example of the use of judicial discretion to determine if technology is a suitable means for the child to have access with its non-custodial parent. As the core of the CRC is the protection of children and treating them on a more equal footing vis-à-vis adults, it is suggested that it is better for children to maintain contact with their parents via technology and nurture their relationship on a regular basis, rather than the relationship between parent and child depending on a weekly access visit or a mid-week telephone call.

\section{Interview-based study and court observations}

An interview-based study conducted by the author reinforces the fact that the majority of non-custodial parents have some level of access to their children. ${ }^{79}$ In total, 40 people were interviewed, made up of 11 solicitors, three barristers and two mediators, as well as 10 fathers and 14 mothers (who were either separated or unmarried). ${ }^{80}$ Participants in the study were selected by means of a convenience sample which is defined by Bryman as one "that is simply available to the researcher by means of its accessibility". 81 The solicitors, barristers and mediators were selected on the basis of their expertise in the area of family law. Several methods were employed to recruit parents for the study. Initially, parent groups were contacted to access suitable interviewees, but while some contacts were made via fathers' rights groups, attempts to contact mothers by this method proved more difficult. Two further methods were also employed. Individual solicitors offered to approach their clients resulting in one quarter of the female participants being contacted in this way. The remainder of the female interviewees were referred to the researcher by personal acquaintances. Only 30 per cent of fathers had contact with fathers' rights organisations, while one father was involved in a lone parents' group. The remainder of fathers were contacted through personal acquaintances or through recommendations from the professionals interviewed. The primary method of data collection was semi-structured, faceto-face interviews. While the method is time-consuming, it facilitates the collection of indepth information about the personal experiences of participants and enables researchers to properly assess and understand the views of all parties interviewed. The data were subsequently analysed using qualitative thematic analysis, by means of coding, to examine the presence of recurring themes and issues that emerged during the interview process.

The study found that while 45 per cent of separated mothers interviewed had joint custody with their former husband, the children resided with their mother who was the primary carer. One-third of the unmarried fathers had joint custody, but again in all such

77 D Welsh "Virtual parents: how virtual visitation legislation is shaping the future of custody law" (2008) 11(1) Journal of Law and Family Studies 215-25, p. 223.

78 Doek, Commentary, n. 70 above, p. 30.

79 The interview-based study was conducted by the author as part of doctoral research (unpublished). The title of the thesis is The Rights and Responsibilities of Fathers in Irish Family Law.

80 Six fathers were separated while the remainder were unmarried. Ten mothers were separated with four mothers unmarried.

81 A Bryman, Social Research Methods (Oxford: OUP 2001), p. 97. While geographical spread was not a prerequisite of this research, it appeared desirable that the research be conducted in more than one area, in order to ascertain the experiences of participants in different District Court and Circuit Court areas. The exact locations and identities of the participants have been disguised, in order to protect the anonymity of the professionals and individuals involved in the research. 
cases the children resided with their mother. ${ }^{82}$ By contrast, 83 per cent of the separated fathers had joint custody, with only one father having day-to-day care of the children. Unmarried parents on the other hand, were more likely to have sole custody, with all of the unmarried mothers interviewed having sole custody, and one unmarried father having dayto-day care of his children. Conversely, 88 per cent of fathers had access arrangements in relation to their children but almost half of the solicitors interviewed recognised that children can be used as a "pawn", or as a "stick" in separation cases. ${ }^{83}$ A minority of solicitors in the study noted that when fathers initially attend for consultation, they frequently request equal time with their children, but this does not always work in reality, primarily because of accommodation or working arrangements. ${ }^{84}$ The mothers in the study also acknowledged that the majority of fathers had secured access rights to their children. ${ }^{85}$ Separated fathers were more likely to have more flexible arrangements in relation to access but only two separated fathers stated that they were happy with the amount of access available to them, as they saw their children daily. In particular, non-custodial fathers spoke about the difficulties of not seeing their children daily. Those difficulties included missing out on the day-to-day contact with their children, missing their children growing up, and being left out of decision-making in relation to the child.

To supplement the findings in the interview-based study, an application was made by the author under s. 40(3) of the Civil Liability and Courts Act 2004, ${ }^{86}$ to the Department of Justice, Equality and Law Reform to attend family law courts as a bona fide researcher attached to an academic institution. ${ }^{87}$ As a researcher in a nominated body under the Universities Act 1997, there was an entitlement to apply. ${ }^{88}$ Overall, the research in the family courts was conducted by attending the Circuit Family Courts for five days and the District Family Courts for four days. ${ }^{89}$

While the most common applications observed in the District Court were applications to make or vary maintenance orders, the second most common applications in this court were applications to either make or vary an access order. ${ }^{90}$ Applications for access were predominantly made by men (63 per cent) but in seven ( 37 per cent) cases women were the applicants. Access was not denied by the judge to any applicant who sought it. This again was in line with the interview-based study previously mentioned, the vast majority of noncustodial fathers having access to their children. In one case before the District Court, a mother sought access as she had not seen her children due to her own ill health. The father

82 This result is similar to the Courts Service report, Family Matters, in 2007 which indicated that while joint custody was granted in the majority of the custody cases studied, the children remained living with their mothers - see Courts Service, Family Matters (Dublin: Courts Service 2007), p. 26. See also S Conneely, Family Mediation in Ireland (Aldershot: Ashgate Publishing 2002), p. 211, which found that in 89 per cent of cases surveyed, children of the family resided with their mother.

8345 per cent of solicitors.

8427 per cent of solicitors suggested this.

8577 per cent of mothers stated this.

86 The categories of persons who may attend family law courts under SI 337/2005 are: family mediators, persons engaged in family law research who are either nominated by a body specified or approved by the minister or persons engaged by the Court Service to prepare court reports of proceedings under relevant enactments.

87 While the family law court sittings in Ireland are held in camera, the Civil Liability and Courts Act 2004 permits specified persons to apply to attend court and observe cases in these courts.

88 The Universities Act 1997 refers to all National University of Ireland colleges namely those located in Galway, Cork, Dublin and Maynooth. Other specified bodies refer inter alia to Trinity College, Dublin, Institutes of Technology and the Law Reform Commission.

89 Permission was granted by the Minister for Justice, Equality and Law Reform and visits to court were held over a three-month period.

9021 cases (19 per cent) related to access. 
was opposed to any access being granted due to the nature of her illness. The judge, however, suggested supervised access as her children had expressed concerns about their mother's mental state. The judge stated that "she is entitled to access" but the judge stressed that "until I am satisfied beyond doubt, there will be supervised access" until full psychiatric reports were available.

In a minority of cases if there was any doubt in relation to the child's safety the judge ordered supervised access or declared that the interim access order remain in place until an s. 20 report had been sought. ${ }^{1}$ An s. 20 report under the Child Care Act 1991 may be sought by the court from the local Health Service Executive in order to undertake an investigation of the child's circumstances. The report gives direction on issues such as custody and access and unless the report indicates significant danger to the child's welfare, the judge will give due credence to the report's findings. If there is doubt about the suitability of the applicant parent in relation to access the judge can order supervised access or can suspend interim access orders already in place. If during the course of a case it is made known to the judge that a child may be in danger, then the judge may order an s. 20 report and adjourn proceedings until such time as this report is received.

A judge also has jurisdiction to order a social report under s. 47 of the Family Law Act $1995,{ }^{92}$ relating to any party to the proceedings or to any other person to whom the proceedings relate, including children. ${ }^{93}$ Shannon states that, since the introduction of social reports, "they have become widely used as tools in the resolution of child-centred disputes".94 In the court observations, however, it was noted that no judge ordered an s. 47 report. ${ }^{95}$

Nevertheless, in 11 cases (10 per cent) witnessed in the District Family Court, an s. 20 report was an integral part of the proceedings in that the judge gave due consideration to a report handed into court or he/she ordered an s. 20 report to be prepared before deciding on these issues and adjourned the case pending the handing in of the report. The more contentious and longer cases in the District Family Court related to issues of access between non-marital couples. For fathers, it can be more difficult to maintain a relationship with their child, as they are more likely to be the non-custodial parent, in particular as they may no longer live in the family home or sometimes within the same district. The CRC therefore is particularly important for these fathers as Article 9(1) suggests that children should not be separated from their parents against their will, while Article 9(3) obliges state parties to respect the child's right to contact with both parents. It appears therefore, that unless it is contrary to the child's best interests, the child should have regular contact with both parents.

91 In 14 per cent of access applications, supervised access was granted.

92 S. 47(1) of the Family Law Act 1995 states: "In proceedings to which this section applies, the Court may, of its own motion or on application to it in that behalf by a party to the proceedings, by order give such directions as it thinks proper for the purpose of procuring a report in writing on any question affecting the welfare of the party to the proceedings or any other person to whom they relate from (a) such probation and welfare officer . . . as the Minister for Justice may nominate, (b) such person nominated by a health board specified in the order as that board may nominate, being the person who, in the opinion of that board, is suitably qualified for the purpose, or (c) any other person specified in the order."

93 The equivalent section in the Family Law (Divorce) Act 1996 is s. 42 which directs that s. 47 of the Family Law Act 1995 applies to divorce proceedings.

94 G Shannon, Family Law 2nd edn (Oxford: OUP 2003), p. 57.

95 Clissmann and Hutchinson are critical of the s. 47 reports as they argue that the process of obtaining such reports is slow and thus causes delays in the proceedings - see further I Clissmann and P Hutchinson, "The right of the child to be heard in guardianship, custody and access cases (II)" (2006) 2 Irish Journal of Family Law 2-7, p. 3. 


\section{Incorporating the CRC in Ireland}

It is submitted that the incorporation of the CRC into Irish law could ensure increased rights for children in our society and would lead to a more child-centred approach in Irish family law. By default, it could lead to better protection for fathers, particularly those who have difficulty securing access to their children post-separation, because Article 9(3) of the $\mathrm{CRC}$, in particular, promotes the right of children to maintain contact with their parents and Article 12 gives them a right to have their views heard on all issues affecting them.

In the concluding observations by the CRC on Ireland's second report in 2005, the Committee recommended that Ireland:

Strengthen its efforts to ensure, through Constitutional provisions, that children have the right to express their views in all matters affecting them and to have those views given due weight in particular in families, schools and other educational institutions, the health sector and in communities. ${ }^{96}$

In the second report in 2005, the government announced that a Constitutional Referendum on Children's Rights would be held and a Joint Oireachtas Committee on the Constitutional Referendum on Children (the Joint Committee) was established in $2007 .{ }^{97}$ In February 2010, this Joint Committee published its proposed wording of the constitutional amendment, the proposal being to amend the existing Article 42 of the Constitution with a more child-focused alternative. ${ }^{98}$ The focus of the present Article 42 is on parents' right to educate their children and the right of the state to intervene only if parents fail in their duty towards their children. ${ }^{99}$ The criteria for intervention in marital families is high, ${ }^{100}$ as has been determined in JH (an infant): KC and AC v An Bord Uchtála ${ }^{101}$ where Finlay CJ in the Supreme Court held that the welfare of the child "is to be found within the family, unless the Court is satisfied on the evidence that there are compelling reasons why this cannot be achieved". 102

96 Concluding Observations by the United Nations Committee on the Rights of the Child on Ireland's second report CRC/C/IRL/CO/2, para. 25.

97 In February 2007, the government published the Twenty-Eight Amendments to the Constitution Bill but the original wording outlined that year was scrapped.

98 www.irishpressreleases.ie/2010/02/16/joint-committee-on-the-constitutional-amendment-on-childrenpublishes-wording-for-the-proposed-constitutional-amendment-concerning-the-acknowledgement-andprotection-of-the-rights-of-children. The full document is available on www.oireachtas.ie/documents/ committees30thdail/j-conamendchildren/reports_2008/20100218.pdf.

99 Article 42.5 of the Constitution states: "In exceptional cases, where the parents for physical or moral reasons fail in their duty towards their children, the State as guardian of the common good, by appropriate means shall endeavour to supply the place of the parents, but always with due regard to the natural and imprescriptible rights of the child."

100 For example, s. 3(1) of the Adoption Act 1988 specifies that a child of a marital family can only be adopted if parents have failed for physical or moral reasons in their duty towards the child; it is likely that such failure will continue without interruption until the child attains the age of 18 years; that such failure constitutes an abandonment on the part of the parents of all parental rights and that by reason of such failure, the state, as guardian of the common good, should supply the place of the parents. This section also specifies that for such an adoption order to be made, it must be in the best interests of the child to do so.

101 [1985] IR 375.

102 Ibid. para. 395. In this case, an unmarried mother placed her child for adoption and before the final adoption order was made, she changed her mind and married the father of the child. The marriage to the father legitimised the child and therefore the child and its natural parents constituted a family under Articles 41 and 42 of the Constitution. 
At present, while the welfare principle is promoted by legislation, ${ }^{103}$ the primacy of the family, and, in particular, the marital family under Article 41, ${ }^{104}$ is inhibiting the rights of children to be placed at the heart of all decisions affecting them. The supremacy of the constitutional marital family was never more apparent than in the Baby Ann case, ${ }^{105}$ where the Supreme Court held that a young couple who married after they had placed their child for adoption could have the child returned to them. McGuinness J held that the case must be "decided under the Constitution and the law as it now stands"106 and unless compelling reasons existed, a child of a marital family could not be adopted. ${ }^{107}$

The proposed amendment, therefore, if passed, would raise the rights of children to a constitutional level. In particular, the welfare principle would be constitutionally recognised as the amended Article 42(2) would read:

The State recognises and acknowledges the natural and imprescriptible rights of all children including their right to have their welfare regarded as a primary consideration and shall, as far as practicable, protect and vindicate those rights.

Further, Article 42(3) would read "in the resolution of all disputes concerning the guardianship, adoption, custody, care or upbringing of a child, the welfare and best interests of the child shall be the first and paramount consideration".

Particularly important is the proposal at Article 42(2) which states:

The State guarantees in its laws to recognise and vindicate the rights of all children as individuals including:

i the right of the child to such protection and care as is necessary for his or her safety and welfare;

ii the right of the child to an education;

iii the right of the child's voice to be heard in any judicial and administrative proceedings affecting the child, having regard to the child's age and maturity.

Kilkelly comments that the proposed Article 42(2) is a "clear recognition of the status of children as right-holders, independent of adults". ${ }^{108}$ Thus, children would not only have a right to protection and care and a right to education, but also a right to have their voices heard in any proceedings affecting them. The Joint Committee observed that:

[i]t is the view of the Committee that our laws and services for children should be in accordance with the State's obligations under the United Nations Convention on the Rights of the Child. ${ }^{109}$

103 S. 3 of the Guardianship of Infants Act 1964.

104 Article 41.3.1 pledges to "guard with special care the institution of Marriage, on which the Family is founded, and to protect it from attack".

$105 \mathrm{~N}$ and Another v Health Service Executive and Others [2006] 4 IR 374.

106 Ibid. para. 498. In the High Court, McMenamin J had held that the child would be psychologically damaged if she was taken away from her prospective adoptive parents as she had formed an emotional bond with them and concluded that compelling reasons had been established - para. 466.

107 See also North Western Health Board v HW and CW [2001] 3 IR 622 where the marital parents refused to have their child undergo a heel prick/PKU test after birth. The state wished to take the child into care but the Supreme Court held that while the parents' decision was ill-advised, it did not constitute a failure in their duty to their child. Hardiman J commented that Article 42.5, which permits the state to intervene in exceptional circumstances, "does not constitute the State as an entity with general parental powers" - para. 757.

108 U Kilkelly, "A brave new model for the rights of Irish children”, available at www.irishtimes.com/newspaper/ opinion/2010/0218/1224264713713_pf.html.

109 Joint Committee, n. 98 above, p. 20. 
This amendment, if passed, would bring a child-focused alternative in relation to any decisions made by adults on their behalf. In particular it would emphasise the right of a child to maintain contact with his or her parents and a right to have the voice of the child heard, unless it was contrary to the child's best interests to do so.

\section{Constitutional amendment}

The Joint Committee discussed the possibility of direct incorporation of the CRC in the Constitution but suggested that such direct incorporation would give "rise to complex and difficult issues" in particular in relation to the rights of parents already enshrined in Article 41 of the Constitution. ${ }^{110}$ This is due to the fact that the rights in relation to children under the Convention are extensive and include not only civil and political rights but also economic, social and cultural rights. At present under Article 41, the marital family is deemed to possess inalienable and imprescriptible rights which could, the Committee suggested, be in conflict with the state's duty to protect the institution of marriage. ${ }^{111}$ Further, the Joint Committee stated that "many of the rights provided for in the Convention inhere in children under the provisions of Article 40 of the Irish Constitution". ${ }^{112}$ For example, in the State (Nicolaou) v An Bord Uchtála, ${ }^{113}$ a case which was factually similar to the Keegan case, an unmarried father argued that his constitutional rights as a father were being infringed due to the fact that his child was adopted and his consent to the adoption was not required. The Supreme Court ruled that an unmarried father is outside the scope of Article 41, as is an unmarried mother but that an unmarried mother may have rights under Article 40.3 of the Constitution. ${ }^{114}$ Walsh J. stated:

the mother of an illegitimate child does not come within the ambit of Article 41 and 42 of the Constitution. Her natural right to the custody and care of her child, and such other natural personal rights as she may have ... fall to be protected under Article 40, section 3, and are not affected by Article 41 or 42 of the Constitution. ${ }^{115}$

In other words, while unmarried mothers do not fall within the scope of Articles 41 and 42 of the Constitution, Article 40.3 protects their right to the care and custody of their children. As O'Higgins CJ observed in $G \mathrm{v}$ An Bord Uchtála, ${ }^{116}$ an unmarried mother has:

rights which derive from the fact of motherhood and from nature itself . . . as a mother, she has the right to protect and care for, and to have custody of, her infant child. ${ }^{117}$

As an acknowledgment that children are inherently protected under Article 40, the Committee instead opted for specific rights for children, such as a right to be heard.

110 Article 41.1.1: "The State recognises the Family as the natural and fundamental unit group of Society"; and Article 41.3.1: "The State pledges itself to guard with special care the institution of Marriage, on which the Family is founded, and to protect it from attack."

111 Joint Committee, n. 98 above, p. 71.

112 Ibid.

113 [1966] IR 567. An Bord Uchtála is the Adoption Board. It has recently been renamed as the Adoption Authority of Ireland since the introduction of the Adoption Act 2010.

114 "The State guarantees in its laws to respect, and, as far as practicable, by its laws to defend and vindicate the personal rights of the citizen."

115 [1966] IR 567, paras 643-4.

116 [1980] IR 32.

117 Ibid. para. 55. 


\section{Conclusion}

The primacy of the marital family under Articles 41 and 42 of the Constitution has meant that children are not given the status they deserve in Ireland at present. While legislation has recognised the welfare principle as the foundation stone of all matters relating to children, ${ }^{118}$ the Baby Ann case suggested that a child who was seen to have bonded with its prospective adoptive parents could be returned to her natural (and now married) parents. Further, if a child-centred decision had been granted in the Keegan case, then it would be unlikely that a child would be adopted where a natural unmarried parent wished to rear that child. Ryan states that: "[i]n principle, the child's right to have meaningful support from and contact with both parents should be respected regardless of the marital status of her parents". 119

A positive outcome, however, from the interview-based study conducted by the author was that the majority of non-custodial parents had access to their children. This finding was reinforced in the observations in the courts as judges invariably granted a right to access unless exceptional circumstances existed. In the courts, it was also found that, where there was doubt in relation to the capability of the non-custodial parent, then supervised access was granted. In order to promote continued contact between non-custodial parents and children, there may be a need for an increased use of technology to enable this to occur, particularly as parent and child's contact will change as a child grows both emotionally and socially.

The incorporation of the CRC would mean that there is a recognition that children have a right to be cared for by both parents. Therefore, unless it is not in a child's best interests to have access to one parent, the child will have some relationship with the non-custodial parent. As De Londras and Kelly state, the "incorporation of an international treaty can take place at a constitutional or sub-constitutional level". ${ }^{20}$ The incorporation of the CRC cannot be realised, however, until, firstly, a constitutional amendment on children has taken place by way of a referendum. The Joint Committee recommended the inclusion of some of the central principles of the CRC in the Constitution, namely the right to equality, a right to be heard, and the child's welfare as the first and paramount consideration in any application concerning their care. ${ }^{121}$ An essential element of promoting children's rights is a right to have their voices heard in proceedings affecting them. From the point of view of the non-custodial parent, if the wishes of a child were promoted then that child may wish to have further access with that parent, and a court may be more predisposed to grant further access. The provision to have separate legal representation for children is therefore vitally important, either by means of a GAL or by means of social reports so that children can express their views through their representatives in a non-adversarial environment. The failure to implement s. 28 of the Guardianship of Infants Act 1964 to allow for a GAL in private law proceedings is a stumbling block to this progression.

It is submitted that Ireland's failure thus far to hold a referendum in relation to children is contrary to the principles of the CRC. The Joint Committee suggested that any proposed legislation in relation to such an amendment be published simultaneously with the amendment to allow the electorate to make an informed decision on the proposals. ${ }^{122}$ The

118 S. 3 of the Guardianship of Infants Act 1964.

119 F Ryan, "Recognising family diversity: children, one-parent families and the law" (2006) 9(1) Irish Journal of Family Law 3-10, p. 5.

120 F De Londras and C Kelly, European Convention on Human Rights Act: Operation, impact and analysis (Dublin: Round Hall/Thomson Reuters 2010), p. 9.

121 Joint Committee, n. 98 above, p. 71.

122 Ibid. p. 86. 
Minister for Children and Youth Affairs, Barry Andrews, recently acknowledged that constitutional reform will be the "lasting legacy of the Convention [CRC] in this country". 123 There is a move to hold a referendum on children's rights in 2011, which Minister Andrews suggested "could be as early as the first quarter of next year", 124 but until this has taken place and has been passed by the people of Ireland, ${ }^{125}$ the CRC will remain a source of guidance and not law for the foreseeable future.

123 Press Release on 20 November 2010 to mark the 21 st anniversary of the CRC in Ireland: "Minister Andrews hopes constitutional reform will be 'lasting legacy' of the Convention in Ireland" - see Children's Rights Alliance at www.childrensrights.ie.

124 Minister Andrews gave this speech two days before the announcement that a general election would be held in January 2011 and a possibility exists that the referendum could be put on hold until political stability is in place.

125 Articles 46 and 47 of the Constitution. 
